\title{
Rectal Small Cell Carcinoma
}

National Cancer Institute

\section{Source}

National Cancer Institute. Rectal Small Cell Carcinoma. NCI Thesaurus. Code C60639.

An aggressive, high-grade, and poorly differentiated carcinoma with neuroendocrine

differentiation that arises from the rectum. It is characterized by the presence of malignant small cells. 